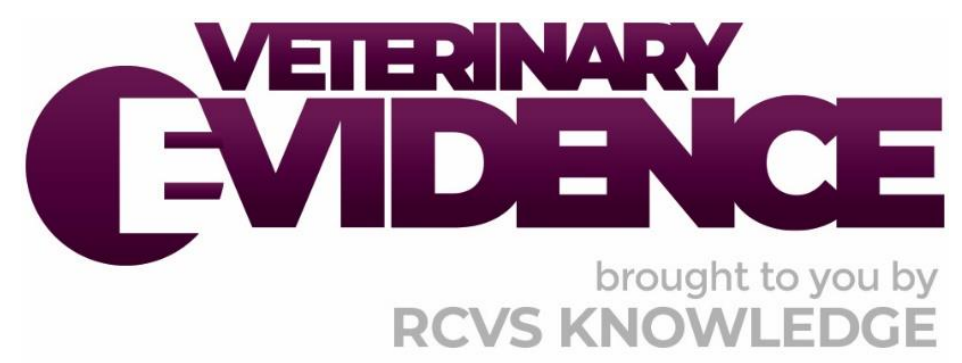

\title{
It is unclear what impact pheromonotherapy has on stress in dogs in shelter environments
}

\author{
A Knowledge Summary by
}

Tighearnan F. Mooney BVMSci (Hons) MRCVS ${ }^{1 *}$

\footnotetext{
${ }^{1}$ Veterinary School Main Building, University of Surrey, Daphne Jackson Road, Guildford, GU2 7AL *Corresponding Author (tfmooneymrcvs@gmail.com)
}

ISSN: 2396-9776

Published: 19 Jun 2020

in: Vol 5, Issue 2

DOI: $10.18849 / \mathrm{VE} . \mathrm{V} 512.278$

Reviewed by: Laura Dixon (PhD BSc) and Debbie Emmerson (MSc) 
KNOWLEDGE SUMMARY

\section{PICO question}

In dogs in shelters does pheromonotherapy reduce stress compared to untreated dogs?

\section{Clinical bottom line}

\section{Category of research question}

\section{Treatment}

\section{The number and type of study designs reviewed}

Two studies were evaluated, one was a prospective blinded randomised placebo-controlled study (Tod et al., 2005) and the other was a prospective unblinded repeated measures study

\section{Strength of evidence}

The papers evaluated provide a weak-to-moderate strength of evidence, due to the limited sample size and short duration of the intervention

\section{Outcomes reported}

In both studies pheromonotherapy resulted in a statistically significant reduction in mean bark amplitude but not in duration or peak bark amplitude. Neither study found a significant change in expression of fear-related behaviours in response to a neutral stranger or a stressor

\section{Conclusion}

Based on the studies assessed in this Knowledge Summary it is not possible to determine if pheromonotherapy reduces stress in dogs in shelter environments. It cannot be determined whether the small absolute reduction in bark amplitude present in both studies is clinically or biologically significant. Additionally, barking is a non-specific behaviour (Protopopova, 2016; Pongráczet al., 2010; Taylor \& Mills, 2007; and Yin, 2002), so these results cannot be interpreted as a reduction in stress without further study.

It is beyond the scope of this Knowledge Summary to comment on any perceived or apparent difference in the effectiveness of pheromonotherapy in the shelter environment compared to the home environment

\section{How to apply this evidence in practice}

The application of evidence into practice should take into account multiple factors, not limited to: individual clinical expertise, patient's circumstances and owners' values, country, location or clinic where you work, the individual case in front of you, the availability of therapies and resources.

Knowledge Summaries are a resource to help reinforce or inform decision-making. They do not override the responsibility or judgement of the practitioner to do what is best for the animal in their care. 


\section{Clinical Scenario}

A healthy young dog has been bought into a shelter by a member of the public, it is obvious that the animal is owned however the owner cannot be identified or contacted. The shelter has decided that the dog would be suitable for adoption if unclaimed by the owner, and as such it has been placed into the shelter's kennels while attempts are made to locate the owner. The dog quickly becomes distressed, frequently displaying avoidance and displacement behaviours. You are in charge of the case and believe that the dog requires pharmacological intervention to reduce stress, the only option available to you is pheromonotherapy which you have used successfully in owned animals, however, you remember reading a metanalysis where the efficacy of pheromonotherapy in shelter settings was questioned (Frank et al., 2010).

\section{The evidence}

The systematic literature search identified two prospective studies which directly address the PICO question. One is a blinded randomised placebo-controlled study with a sample size of 54 dogs (Tod et al., 2005), in terms of study design and sample size this is the stronger of the two papers, and was the only relevant study included in Frank et al.'s (2010) metanalysis. The other study is a repeated measures study with a sample size of 25 dogs (Hermiston et al., 2018). Neither paper is very powerful due to the small sample size and short duration of interventions.

\section{Summary of the evidence}

Tod et al. (2005)

\begin{tabular}{|c|c|}
\hline Population: & $\begin{array}{l}\text { Dogs present in a Scottish animal shelter - not undergoing } \\
\text { behavioural therapy, psychopharmacological intervention, or less } \\
\text { than } 6 \text { months old. 22/54 participants were mongrels, the remaining } \\
32 \text { participants were classified into } 9 \text { breed types (Pointer, German } \\
\text { Shepard Dog type, Terrier type, Labrador type, Staffordshire bull, } \\
\text { Dalmatian type, Jack Russell, Collie cross, and Border Collie type). } \\
\text { More male dogs were enrolled than female ( } 34 \text { compared to 20), } \\
\text { reflecting the intake population at the shelter. The ages of } \\
\text { participants were not controlled for as the information was often } \\
\text { not available or accurate }\end{array}$ \\
\hline Sample size: & $n=54$ dogs \\
\hline Intervention details: & $\begin{array}{l}\text { - } 37 \text { dogs were enrolled in the treatment and } 17 \text { dogs in the } \\
\text { control group, the study did not detail how dogs were } \\
\text { assigned to these groups } \\
\text { On day } 0 \text { before a diffuser was installed, a baseline for } \\
\text { barking amplitude, barking duration, and expression of } \\
\text { behaviours associated with high and low intensity fear was } \\
\text { recorded. The dogs were exposed to a neutral and friendly } \\
\text { stranger, and behaviours expressed were recorded } \\
\left.\text { Dog Appeasing Pheromone diffuser (D.A.P }{ }^{\circledR}\right) \text { or placebo } \\
\text { diffuser plugged into electrical outlet above the internal } \\
\text { kennel } \\
\text { At the end of the } 7 \text { days exposure period the same measures } \\
\text { of barking amplitude, barking duration, and behavioural } \\
\text { expression were made } \\
\text { Between test groups a } 7 \text { day wash out period was enforced } \\
\text { in the kennels to dissipate circulating pheromones to } \\
\text { baseline }\end{array}$ \\
\hline
\end{tabular}




\begin{tabular}{|c|c|}
\hline Study design: & Blind, randomised, placebo-controlled design \\
\hline Outcome studied: & $\begin{array}{l}\text { - Whether pheromonotherapy altered: } \\
\quad \text { barking amplitude (measured in decibels) or } \\
\text { duration } \\
\circ \quad \text { performance of behaviours associated with high and } \\
\text { low intensity fear response } \\
\text { - Behaviours displayed in response to neutral or friendly } \\
\text { strangers }\end{array}$ \\
\hline $\begin{array}{l}\text { Main findings: } \\
\text { (relevant to PICO question): }\end{array}$ & $\begin{array}{l}\text { - There was a statistically significant reduction in mean } \\
\text { barking amplitude in the treatment group compared to the } \\
\text { placebo group on day } 7 \text { (no significant difference on day 0) } \\
\text { [Average absolute difference was } 20 \mathrm{~dB} \text { ] } \\
\text { - There was no statistically significant change in peak barking } \\
\text { amplitude in the placebo or treated groups } \\
\text { - On day } 7 \text { there was a significant increase in expression of } \\
\text { resting and sniffing behaviours in the treated group in } \\
\text { response to the friendly stranger } \\
\text { - On day } 7 \text { there was no significant difference in expression of } \\
\text { fear behaviours between the placebo and treated groups in } \\
\text { response to the neutral stranger }\end{array}$ \\
\hline Limitations: & $\begin{array}{l}\text { - The paper does not specify how dogs were randomised and } \\
\text { assigned to the treatment or control groups } \\
\text { - Assesses barking which was not specific to fear, anxiety, } \\
\text { stress, or aggression (Protopopova, 2016; Pongrácz et al., } \\
\text { 2010; Taylor \& Mills, 2007; and Yin, 2002) } \\
\text { - Although the authors controlled for kennel design and } \\
\text { construction materials, barking amplitude and duration was } \\
\text { measured for the whole kennel block (multiple animals) } \\
\text { rather than the individual animal with pheromone diffuser in } \\
\text { the kennel, this may have contributed to the fluctuation in } \\
\text { bark amplitude over the minute recorded (however the } \\
\text { diffuser was rated to cover the entire kennel block and } \\
\text { therefore should have affected all animals) } \\
\text { - The other dogs in the kennel block were not kept constant - } \\
\text { some individuals moved out of the block and new individuals } \\
\text { were introduced, therefore although the pheromone } \\
\text { diffuser was rated to cover the entire block not all } \\
\text { individuals had been exposed for the same length of time } \\
\text { No control for individual dog's previous experiences or level } \\
\text { of socialisation when assessing reactions to neutral and } \\
\text { friendly strangers }\end{array}$ \\
\hline
\end{tabular}

Hermiston et al. (2018)

Population: Stray or relinquished dogs present in an English animal shelter. 12 of the 25 participants were cross or mixed breeds, the remaining 13 participants were classified as purebred (Labrador, Great Dane, Springer spaniel, Deerhound, Husky, Akita, Collie, and Staffordshire Bull Terrier). More male dogs (16/25) were enrolled than bitches 


\begin{tabular}{|c|c|}
\hline & $\begin{array}{l}\text { (9/25). Ages varied from } 5 \text { months to } 168 \text { months with a mean of } \\
41.64 \text { months }\end{array}$ \\
\hline Sample size: & $\mathrm{n}=25$ dogs \\
\hline Intervention details: & $\begin{array}{l}\text { - The } 25 \text { participants were split into two groups, } 12 \text { individuals } \\
\text { were exposed to the control then the intervention on } \\
\text { subsequent days, the other } 13 \text { individuals were exposed to } \\
\text { the intervention and then the control on subsequent days } \\
\text { - Control: approximately } 10 \text { second exposure to a stressor (an } \\
\text { unfamiliar dog led past the kennel at } 1 \mathrm{~m} \text { distance) with no } \\
\text { pheromonotherapy } \\
\text { - Intervention: } 2 \text { pumps of a } 60 \mathrm{~mL} \text { pheromone spray (D.A.P }{ }^{\circledR} \\
\text { spray) applied to four corners of a kennel } 30 \text { minutes prior } \\
\text { to an approximately } 10 \text { second long exposure to a stressor } \\
\text { (an unfamiliar dog led past the kennel at } 1 \mathrm{~m} \text { distance) }\end{array}$ \\
\hline Study design: & Repeated measures design \\
\hline Outcome studied: & $\begin{array}{l}\text { Whether pheromonotherapy reduces: } \\
\text { - the frequency that behaviours indicative of canine stress } \\
\text { were displayed } \\
\text { - mean and peak barking amplitude (measured in decibels) } \\
\text { and barking duration }\end{array}$ \\
\hline $\begin{array}{l}\text { Main findings: } \\
\text { (relevant to PICO question): }\end{array}$ & $\begin{array}{l}\text { - There was no significant difference in the display of stress- } \\
\text { related behaviours between the control and intervention } \\
\text { group } \\
\text { There was a statistically significant reduction in barking } \\
\text { intensity when pheromonotherapy was used compared to } \\
\text { the control group (absolute difference of } 6.48 \mathrm{~dB} \text { ) }\end{array}$ \\
\hline Limitations: & $\begin{array}{l}\text { - Assesses barking which is not specific to fear, anxiety, stress, } \\
\text { or aggression (Protopopova, 2016; Pongrácz et al., 2010; } \\
\text { Taylor \& Mills, 2007; and Yin, 2002) } \\
\text { - Did not control for length of stay at the shelter, therefore } \\
\text { some animals may have become habituated to the } \\
\text { environment } \\
\text { - Small sample size } \\
\text { - Control did not incorporate a placebo } \\
\text { - Investigators were not blinded to the treatment }\end{array}$ \\
\hline
\end{tabular}

\section{Appraisal, application and reflection}

According to BSAVA (2017), Adapti ${ }^{\circledR}$, formally branded as D.A.P ${ }^{\circledR}$, (Ceva Santé Animale) is the only pheromone-based product on general sale in the UK for use in dogs. It is therefore unsurprising that although neither of the studies reviewed was supported by Ceva both used Adapti ${ }^{\circledR}$ products as their interventions. Ceva published comprehensive references which support Adaptil's ${ }^{\circledR}$ efficacy in various settings (Ceva Santé Animale, 2015). Of the two studies Ceva cites to support Adaptil's ${ }^{\circledR}$ use in a shelter setting, one was assessed in this Knowledge Summary (Tod et al., 2005), the other was excluded from assessment because it was only published as part of a conference proceeding. The study (Barlow \& Goodwin, 2009) was a double-blind placebo-controlled trial of Dog Appeasing Pheromone (D.A.P ${ }^{\circledR}$ ) infused collars, total sample size was 90 dogs (31 treated collars, 29 placebo collars, 30 controls with no collars) and lasted 10 days. If it had been included this study would have had the largest sample size and longest duration, its results could have added power to the conclusions drawn in this Knowledge Summary, however as the study was published in short form, its 
methodology was not described in detail and it was not possible to evaluate and critique the paper to the degree necessary for inclusion in a Knowledge Summary.

In the two studies reviewed the dogs were exposed to pheromonotherapy for 30 minutes (Hermiston et al., 2018) and 7 days (Tod et al., 2005), both of which are consistent with the onset of actions advertised by Ceva (Adaptil ${ }^{\circledR}$ transport spray should act 'almost immediately' whilst the Adaptil ${ }^{\circledR}$ diffuser should be fully functional within 24 hours (Ceva Santé Animale, 2020)). However, the study durations are short when compared to the 7-21 days target overall length of stay in American shelters (UC Davis Koret Shelter Medicine Programme, 2017) and that Brown et al. (2013) found that the average length of stay for an adult dog in a no-kill shelter is 42 days. This is significant as the interventions applied do not reflect the realities that dogs experience, so these studies cannot accurately predict what impact pheromonotherapy will have in a shelter environment. Additionally, although both studies identified statistically significant reductions in barking amplitude, neither study was able to establish if this reduction was clinically relevant.

Sales et al. (1997) showed that barking has a negative impact on welfare, therefore using barking as part of a composite measure for welfare could be justified. However, barking is also a non-specific behaviour indicative of elevated arousal not stress, fear, or welfare specifically (Protopopova, 2016; and Yin, 2002), which may be socially motivated in shelter environments (Taylor \& Mills, 2007). Additionally, barking behaviours and motivation may have a breed specific component (Pongrácz et al., 2010) which was not controlled for in these studies. Therefore, without further research into the emotional motivations for barking the use of barking amplitude, frequency, or duration as a proxy measure for stress is a limitation for the studies assessed.

Finally, excessive vocalisation was not included in the quality of life assessment tool developed by Kiddie \& Collins (2014) because in a shelter or kennel environment dogs are rarely in auditory or visual isolation which may emphasise the aforementioned social component which can motivate barking. For these reasons future studies may gain more insight into the emotional status of dogs in shelter environments if they chose to assess factors included in the validated quality of life assessment tool.

\section{Methodology Section}

\begin{tabular}{|c|c|}
\hline \multicolumn{2}{|l|}{ Search Strategy } \\
\hline $\begin{array}{l}\text { Databases searched and dates } \\
\text { covered: }\end{array}$ & $\begin{array}{l}\text { - } \quad \text { CAB Abstracts via CAB Direct [2005-2018] } \\
\text { - } \quad \text { UK-Vet via Mag Online Library [2010-2018] } \\
\text { - } \quad \text { Pubus via Scopus.com [1976-2018] } \\
\text { - } \text { Medline via the NCBI interface [2000-2018] } \\
\text { - Web of Science via the Web of Knowledge interface [2005- } \\
\text { 2018] }\end{array}$ \\
\hline Search terms: & $\begin{array}{l}\text { [dog OR dogs OR cani*] AND pheromones AND [stress OR behavio?r] } \\
\text { AND shelter }\end{array}$ \\
\hline Dates searches performed: & $31 / 01 / 2019$ \\
\hline
\end{tabular}




\begin{tabular}{|r|l|}
\hline Exclusion / Inclusion Criteria & \\
\hline Exclusion: & $\begin{array}{l}\text { - No mention of dogs } \\
\text { - No pheromonotherapy intervention to reduce stress }\end{array}$ \\
& $\begin{array}{l}\text { - Not in a shelter setting } \\
\text { - Case report, case series, book, guidance, policy, conference } \\
\text { proceedings, correspondence }\end{array}$ \\
\hline Inclusion: & $\begin{array}{l}\text { Must discuss the impact of pheromonotherapy on stress in dogs in a } \\
\text { shelter setting }\end{array}$ \\
\hline
\end{tabular}

\begin{tabular}{|c|c|c|c|c|c|c|}
\hline \multicolumn{7}{|c|}{ Search Outcome } \\
\hline Database & $\begin{array}{l}\text { Number } \\
\text { of } \\
\text { results }\end{array}$ & $\begin{array}{l}\text { Excluded - } \\
\text { No shelter }\end{array}$ & $\begin{array}{c}\text { Excluded-No } \\
\text { pheromonotherapy } \\
\text { stress intervention }\end{array}$ & $\begin{array}{c}\text { Excluded - No } \\
\text { canine }\end{array}$ & $\begin{array}{l}\text { Excluded-Case } \\
\text { study, } \\
\text { guidance, } \\
\text { policy, } \\
\text { conference } \\
\text { proceeding, or } \\
\text { correspondence }\end{array}$ & $\begin{array}{c}\text { Total } \\
\text { relevant } \\
\text { papers }\end{array}$ \\
\hline $\begin{array}{l}\mathrm{CAB} \\
\text { Abstracts }\end{array}$ & 10 & 4 & 2 & 0 & 2 & 2 \\
\hline UK-Vet & 8 & 3 & 1 & 4 & 0 & 0 \\
\hline Scopus & 35 & 13 & 15 & 5 & 0 & 2 \\
\hline PubMed & 1 & 1 & 0 & 0 & 0 & 0 \\
\hline Medline & 2 & 1 & 1 & 0 & 0 & 0 \\
\hline $\begin{array}{l}\text { Web of } \\
\text { Science }\end{array}$ & 19 & 6 & 8 & 0 & 5 & 2 \\
\hline Total relev & 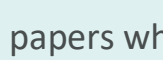 & . & & & & 2 \\
\hline
\end{tabular}

\section{CONFLICT OF INTEREST}

The author declares no conflict of interest. 


\section{REFERENCES}

1. Barlow, N. \& Goodwin, D. (2009). 'Efficacy of Dog Appeasing Pheromone (D.A.P. ${ }^{\circledR}$ ) in reducing stress related responses in rescue shelter dogs', Proceedings of the Companion Animal Behaviour Therapy Study Group.

2. Brown, W., Davidson, J. \& Zuefle, M. (2013). 'Effects of Phenotypic Characteristics on the Length of Stay of Dogs at Two No Kill Animal Shelters', Journal of Applied Animal Welfare Science, 16(1), 12-18. DOI: https://doi.org/10.1080/10888705.2013.740967

3. BSAVA (2017). 'BSAVA Small Animal Formulary, Part A: Canine and Feline: Dog Appeasing Pheromone' 9th Ed. Wiley.

4. Ceva Santé Animale (2020). ADAPTIL Product FAQs: learn about ADAPTIL Home Diffuser \& learn about ADAPTIL Transport.

5. Ceva Santé Animale (2015). EU Comprehensive References: Feliway \& Adaptil.

6. Frank, D., Beauchamp, G. \& Palestrini, C. (2010). 'Systematic review of the use of pheromones for treatment of undesirable behavior in cats and dogs', Journal of the American Veterinary Medicine Association, 236(12), 1308-1316. DOI: https://doi.org/10.2460/javma.236.12.1308

7. Hermiston, C., Montrose, V. \& Taylor, S. (2018). 'The Effects of dog-appeasing pheromone stray upon canine vocalizations and stress-related behaviours in a rescue shelter', Journal of Veterinary Behavior, 26, 11-16. DOI: http://doi.org/10.1016/i.jveb.2018.03.013

8. Kiddie, J. \& Collins, L. (2014). 'Development and validation of a quality of life assessment tool for use in kennelled dogs (Canis familiaris)', Applied Animal Behaviour Science, 158, 57-68. DOI: https://doi.org/10.1016/i.applanim.2014.05.008

9. Pongrácz, P., Molnár, C. \& Miklósi, A. (2010). 'Barking in family dogs: an ethological approach', The Veterinary Journal, 183(2), 141-147. DOI: https://doi.org/10.1016/i.tvjl.2008.12.010

10. Protopopova, A. (2016). 'Effects of sheltering on physiology, immune function, behaviour, and the welfare of dogs', Physiology \& Behaviour, 159, 96-103. DOI:

https://doi.org/10.1016/i.physbeh.2016.03.020

11. Sales, G., Hubrecht, R., Peyvandi, A., Milligan, S. \& Shield, B. (1997). 'Noise in dog kennelling: is barking a welfare problem for dogs?', Applies Animal Behaviour Science, 52(3-4), 321-329. DOI: https://doi.org/10.1016/S0168-1591(96)01132-X

12. Taylor, K. \& Mills, D. (2007). 'The effect of kennel environment on canine welfare: a critical review of experimental studies', Animal Welfare, 16(4), 435-447. DOI: https://www.ingentaconnect.com/contentone/ufaw/aw/2007/00000016/00000004/art00003

13. Tod, E., Brander, D. \& Waran, W. (2005). 'Efficacy of dog appeasing pheromone in reducing stress and fear related behaviour in shelter dogs', Applied Animal Behaviour Science, 93 (3-4), 295-308. DOI: https://doi.org/10.1016/i.applanim.2005.01.007

14. UC Davis Koret Shelter Medicine Programme (2017). Adoption Driven Capacity.

15. Yin, S. (2002). 'A new perspective on barking in dogs (Canis familiaris)', Journal of Comparative Psychology, 117(2), 189-193. DOI: http://dx.doi.org/10.1037/0735-7036.116.2.189 


\section{EVIIDEFeE

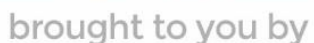 \\ RCVS KNOWLEDGE}

\section{Intellectual Property Rights}

Authors of Knowledge Summaries submitted to RCVS Knowledge for publication will retain copyright in their work, and will be required to grant RCVS Knowledge a non-exclusive license of the rights of copyright in the materials including but not limited to the right to publish, re-

publish, transmit, sell, distribute and otherwise use the materials in all languages and all media throughout the world, and to license or permit others to do so.

\section{Disclaimer}

Knowledge Summaries are a peer-reviewed article type which aims to answer a clinical question based on the best available current evidence. It does not override the responsibility

of the practitioner. Informed decisions should be made by considering such factors as individual clinical expertise and judgement along with patient's circumstances and owners' values. Knowledge Summaries are a resource to help inform and any opinions expressed within the Knowledge Summaries are the author's own and do not necessarily reflect the view of the RCVS Knowledge. Authors are responsible for the accuracy of the content. While the

Editor and Publisher believe that all content herein are in accord with current recommendations and practice at the time of publication, they accept no legal responsibility

for any errors or omissions, and make no warranty, express or implied, with respect to material contained within.

For further information please refer to our Terms of Use.

RCVS Knowledge is the independent charity associated with the Royal College of Veterinary Surgeons (RCVS). Our ambition is to become a global intermediary for evidence based veterinary knowledge by providing access to information

that is of immediate value to practicing veterinary professionals and directly contributes to evidence based clinical decision-making.

https://www.veterinaryevidence.org/

RCVS Knowledge is a registered Charity No. 230886.

Registered as a Company limited by guarantee in England and Wales No. 598443.

Registered Office: Belgravia House, 62-64 Horseferry Road, London SW1P 2AF

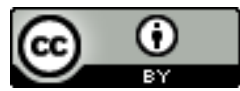

This work is licensed under a Creative Commons Attribution 4.0 International License 